\title{
Proses Berpikir Siswa Bergaya Kognitif Visualizer dalam Menyelesaikan Masalah TIMSS Non Geometri
}

\author{
M. Rohman Galih Tri Mulyo ${ }^{{ }^{*}, A n i s a ~ F a t w a ~ S a r i}{ }^{2}$, and Azhar Syarifuddin ${ }^{3}$ \\ 1*,2,3 Pendidikan Matematika, STKIP Al Hikmah \\ Jalan Elveka V, Kebonsari, Jambangan,Surabaya, Jawa Timur, Indonesia \\ 1*rohmangalih87@gmail.com
}

Artikel diterima: 18-12-2018, direvisi: 23-01-2019, diterbitkan: 31-01-2019

\begin{abstract}
Abstrak
Siswa bergaya kognitif visualizer cenderung mengolah informasi dalam bentuk visual. Tujuan penelitian ini adalah untuk mengetahui proses berpikir siswa bergaya kognitif visualizer dalam menyelesaikan masalah TIMSS non geometri. Penelitian ini merupakan penelitian deskriptif dengan pendekatan kualitatif. Subjek dalam penelitian ini yaitu 3 siswa bergaya kognitif visualizer kelas VIII SMP swasta di Surabaya. Ketiga subjek mempunyai tingkat kemampuan matematika Tinggi, Sedang, dan Rendah. Instrumen penelitian dalam penelitian ini adalah peneliti sendiri dan dibantu dengan instrumen pendukung yaitu angket gaya kognitif visualizer dan verbalizer, soal tes TIMSS non geometri, dan pedoman wawancara. Teknik pengumpulan data yang digunakan yaitu berupa tes gaya kognitif, tanya jawab dengan guru di kelas, tes soal TIMSS non geometri, dan wawancara. Teknik analisis data yang digunakan yaitu reduksi data, penyajian data, dan penarikan kesimpulan. Hasil penelitian siswa berkemampuan matematika tinggi pada tahap persiapan, inkubasi, dan iluminasi sangatlah baik, namun pada tahap verifikasi bisa dikatakan cukup dalam menyelesaikan soal TIMSS non geometri. Siswa yang berkemampuan matematika sedang dari empat tahap sudah cukup baik, namun masih belum mampu memahami soal yang abstrak seperti aljabar. Sedangkan siswa yang berkemampuan matematika rendah pada tahap persiapan dan tahap inkubasi cukup baik, namun pada tahap iluminasi dan tahap verifikasi masih kurang.

Kunci: Proses Berpikir, gaya kognitif visualizer, TIMSS non geometri.
\end{abstract}

\section{Student's of Cognitive Visualizer Thinking Process in Completing Non Geometry Timss Problems}

\begin{abstract}
Students with cognitive visualizer styles tend to process information in visual form. The purpose of this research was to determine the student's thinking process. The purpose of this research is describe student's of cognitive visualizer thinking process in completing non geometry TIMSS problems. The type of this research is desciptive qualitative research. The subjects in this research were three students of cognitive visualizer grade eight from private junior high school in Surabaya. The three subjects had high, medium, and low capability in mathematic. The research instrument in this study was the researchers themselves and assisted by some supporting instruments questionnaire cognitive visualizer and verbalizer, question of TIMSS non geometry, and interviews guidelines. The data collection technique used were a test of style cognitive, interview whit teacher, TIMSS non geometry test, and interview. The data analisis technique used were data reduction, presentation of data, and conclusion. The result of the research was the high-skilled at the stage of preparation, incubation, and illumination well, but in the vierification stage it can be said to be sufficient in solving non geometry TIMSS problems. Students medium-skilled mathematic from four stages are good enough, but still not able to understand abstract questions such as algebra. While students with low-skilled mathematical at the preparation and incubation stages good enough, but at the ilumination and verification stages still not enough.

Keyword: Process of thinking, cognitive visualizer, TIMSS non geometri.
\end{abstract}

Volume 8, Nomor 1, Januari 2019

Copyright @ 2019 Mosharafa: Jurnal Pendidikan Matematika 


\section{Pendahuluan}

Keterampilan berpikir atau proses berpikir siswa merupakan hal penting yang harus diperhatikan oleh setiap guru di Indonesia. Mengingat akan pentingnya ilmu proses berpikir siswa untuk mengetahui pemahaman siswa, sehingga guru mengetahui apakah siswa memang bisa mengerjakan soal atau meniru jawaban temannya. Hal tersebut apabila diperhatikan oleh setiap guru di Indonesia mungkin saja dapat membuat kualitas pendidikan negara kita mampu bersaing dengan negara-negara lainnya. Itulah salah satu faktor kualitas pendidikan di Indonesia masih belum meningkat, hal ini dapat juga dilihat dari hasil tes TIMSS (Third International Mathematics and Science Study) yang dilakukan oleh IEA (International Assiciation for the Evaluation of Educational Achievement). Hasil kegiatan survei TIMSS 2015 menyebutkan bahwa Indonesia menempati rangking ke 45 dari 50 peserta. Siswa Indonesia hanya mencapai level menengah dan masih kesulitan (Nadhifah \& Afriansyah, 2016) atau lemah dalam mengerjakan soal yang membutuhkan penalaran (Rudhito, 2014).

Proses berpikir atau strategi siswa dalam menyelesaikan suatu masalah tentunya tidak lepas dari cara siswa menerima dan mengolah informasi yang didapatkan yang disebut gaya kognitif (Sari, 2016). Menurut Uno (2006) cara berbeda untuk melihat, mengenal, dan mengorganisasi informasi disebut gaya

kognitif. Susan \& Collinson (2015) menyebutkan gaya kognitif mempengaruhi proses berpikir atau strategi penyelesaian suatu masalah. Ide-ide dalam matematika seringkali disampaikan dalam bentuk simbol visual dan simbol verbal. Gaya kognitif yang berkaitan dengan perbedaan penerimaan informasi secara visual maupun verbal adalah gaya kognitif visualizer dan verbalizer. Gaya kognitif visualizer merupakaan salah satu gaya kognitif yang berkaitan dengan penerimaan informasi secara visual. Seseorang yang bergaya kognitif visualizer biasanya cenderung lebih mudah untuk menerima, memproses, menyimpan, dan mengolah informasi dalam bentuk gambar maupun grafik (Sari, 2016).

Banyak penelitian yang berkaitan dengan gaya kognitif Visualizer. Siswa dengan gaya kognitif visualizer cukup baik dalam menyelesaikan masalah geometri, sedangkan siswa bergaya kognitif verbalizer dikategorikan kurang (Winarso \& Dewi, 2017). Sudah banyak penelitian yang mengangkat topik gaya kognitif visualizer dalam menyelesaikan masalah geometri. Sudah banyak pula yang mengangkat permasalahan geometri dilihat dari berbagai perspektif, contohnya analisis proses pemecahan masalah geometri ditinjau dari tahap berpiir van hiele (Sholihah \& Afriansyah, 2017). Oleh karena itu penelitian ini ingin mengangkat topik proses berpikir siswa begaya kognitif visualizer dalam menyelesaikan masalah TIMSS non geometri. Tujuan dilakukannya penelitian ini yaitu untuk mengetahui 
bagaimana proses berpikir siswa bergaya kognitif visualizer dalam menyelesaikan soal TIMSS non geometri.

Soedjadi (2000) menyatakan untuk memahami matematika tidak cukup hanya dengan menghafal tetapi dibutuhkan adanya proses berpikir, karena objek dasar dalam matematika merupakan fakta, konsep, relasi/operasi dan prinsip termasuk hal-hal yang abstrak. Proses berpikir seseorang juga dipengaruhi oleh bagaimana cara seseorang menerima informasi dengan mudah yang biasa disebut gaya kognitif. Menurut Uno (2006) cara berbeda untuk melihat, mengenal, dan mengorganisasi informasi disebut gaya kognitif. Namun dalam penelitian ini difokuskan untuk melihat proses berpikir siswa bergaya kognitif visualizer. Siswa bergaya kognitif visualizer lebih mudah untuk menerima, memproses, menyimpan, dan menggunakan informasi dalam bentuk gambar maupun grafik (Hegarty \& Kozhevnikov, 1999).

Third International Mathematics and Science Study (TIMSS), merupakan studi internasional dalam pendidikan matematika sekolah dan sains yang relatif komprehensif (Hermawan, 2003). TIMSS diselanggarakan oleh International Association for the Evaluation of Educational Achievement (IEA). TIMSS dilakukan dalam waktu 4 tahun sekali, pelaksanaan TIMMS dilakukan dijenjang 4 untuk SD dan jenjang 8 untuk siswa SMP. TIMMS dilakukan untuk mengukur kualitas suatu negara dikatakan sudah baik atau

Mosharafa: Jumal Pendidikan Matematika

Volume 8, Nomor 1, Januari 2019

Copyright $\odot 2019$ Mosharafa: Jurnal Pendidikan Matematika belum baik, namun dalam kegiatan ini difokuskan pada tes matematika dan sains.

\section{Metode}

Penelitian ini termasuk penelitian deskriptif dengan pendekatan kualitatif. Penelitian kualitatif merupakan penelitian yang berlandaskan pada filsafat positivisme, digunakan untuk meneliti pada kondisi yang alamiah, dimana peneliti sebagai instumen inti (Sugiyono,2010). Penelitian ini dilakukan di SMP Swasta di Surabaya semester ganjil tahun pelajaran 2018/2019 bulan Oktober 2018. Subjek penelitian ini yaitu 3 siswa kelas VIII yang masing-masing memiliki gaya kognitif visualizer dan kemampuan matematika tinggi, sedang, dan rendah. Alasan dipilinnya 3 subjek tersebut untuk mempresentasikan masing-masing tingkat kemampuan matematika siswa dan sebagai pembanding antara subjek satu dengan yang lainnya. Sedangkan objek dalam penelitian ini yaitu hasil tes siswa bergaya kognitif visualizer dalam menyelesaikan masalah TIMSS non geometri. Dipilihnya kelas VIII sebagai subjek karena pada umumnya tes TIMSS dilakukan di kelas VIII.

Instrumen penelitian ini terdiri dari instrumen utama dan pendukung. Instrumen utama adalah peneliti sendiri, sedangkan instrumen pendukung meliputi:

a) Angket gaya kognitif (AGK) visualizer dan verbalizer yang diadopsi dari penelitian Jhon $\mathrm{R}$ Kirby dengan judul penelitian verbal and visual learning styles. b) soal TIMSS non geometri tahun 2011 
sebanyak 3 soal yang telah divalidasi oleh dosen pembimbing.

c) Pedoman wawancara mengenai penarikan kesimpulan dan proses berpikir siswa.

Teknik pengumpulan data yang dilakukan yaitu 1). Tes gaya kognitif, tes ini diberikan untuk menentukan calon subjek penelitian. Tes ini dilaksanakan menggunakan angket gaya kognitif untuk klasifikasi siswa bergaya kognitif visualizer ataupun verbalizer. 2) wawancara kepada guru kelas, untuk menentukan 3 siswa yang bergaya kognitif visualizer memiliki kemampuan matematika tinggi, sedang, dan rendah. 3) Tes soal TIMSS, tes dilaksanakan dengan memberikan 3 butir soal TIMSS non geometri. Tujuan pemberian soal non geometri adalah untuk mengetahui bagaimana proses berpikir siswa yang bergaya kognitif visualizer dalam menyelesaikan soal TIMSS non geometri yang membutuhkan kecermatan, dan penalaran. 4) wawancara mengenai hasil pengerjaan siswa menyelesaikan soal TIMSS yang telah diberikan.

Teknik analisis data yang dilakukan dalam penelitian ini yaitu:a) reduksi data, b) penyajian data, dan c) penarikan kesimpulan.

\section{Hasil dan Pembahasan}

Hasil dan pembahasan pada penelitian ini dianalisis dalam beberapa tahap sesuai tahapan proses berpikir kreatif yang meliputi empat tahap yaitu tahapan yang sudah dijelaskan sebelumnya(S Febriani \& N Ratu, 2018).

\section{A. Subjek Berkemampuan Tinggi}

Hasil penelitian pada subjek bergaya kognitif visualizer yang memiliki kemampuan matematika tinggi yaitu pada soal nomor 1 subjek berhasil mengerjakan soal dengan baik. Pada tahap persiapan siswa sudah paham maksud dari soal.

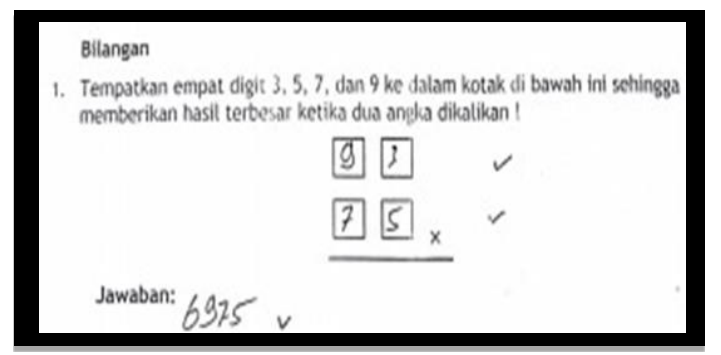

Gambar 1. Soal nomor 1 dan jawaban siswa berkemampuan tinggi

Gambar 1 merupakan soal nomor 1 yaitu soal TIMSS tentang bilangan yang sudah diterjemahkan kedalam bahasa Indonesia.

Untuk mengerjakan soal nomor 1 siswa diminta untuk memasukkan 4 digit nomor yang sudah tersedia kedalam kotak yang telah disediakan dan diminta untuk mencari hasil perkalian yang terbesar. Pada tahap inkubasi siswa ditanya tentang apa yang diketahui dan ditanyakan dalam soal, siswa juga dapat menjelaskan langkah-langkah untuk menyelesaikan masalah nomor 1. Pada tahap iluminasi siswa menyampaikan ide atau rencana yang baik, siswa ditanya tentang rencana yang akan dilakukan untuk menyelesaikan soal ini. Siswa menyampaikan ide yang sangat baik, bahkan siswa ini mampu 
menyampaikan caranya untuk menyelesaikan masalah ini maka siswa ini memilih 93 dan 75 untuk jawaban yang pertama. Siswa ini menempatkan angka yang terbesar untuk menjadi puluhannya karena nanti kalau dikalikan maka menghasilkan nilai yang terbesar. Pada tahap verifikasi, siswa ditanya apakah jawabannya yakin benar. Siswa menjawab yakin benar dan mampu menemukan jawaban yang benar dengan cara 2 kali memilih dan mencoba mengalikan bilangan yang dipilihnya.

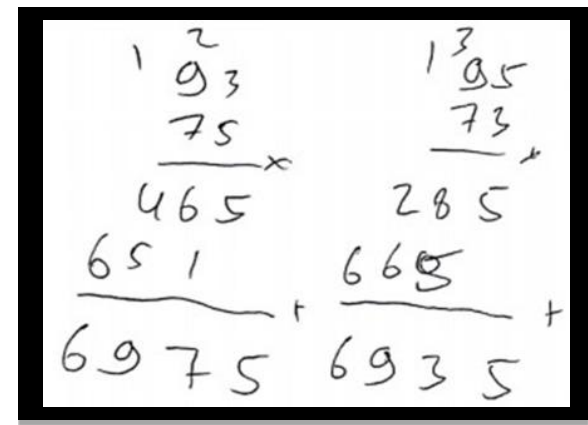

Gambar 2. Hasil pekerjaan siswa berkemampuan tinggi soal nomor 1

Gambar 2 menunjukkan bahwa siswa menyelesaikan nomor 1 dengan 2 kali mencoba mengalikan dengan memilih angka yang terbesar sebagai puluhan dan siswa dapat menjawab soal nomor 1 dengan benar.

Pada soal nomor 2 siswa bergaya kognitif visualizer yang memiliki kemampuan matematika tinggi mampu menyelesaikan soal nomor 2 dengan benar. Pada tahap persiapan siswa diminta memahami soal nomor 2, siswa memahami maksud dari soal nomor 2 .

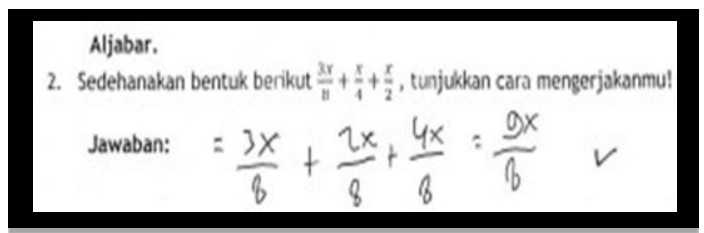

Gambar 3. Soal nomor 2 dan jawaban siswa berkemampuan tinggi

Gambar 3 merupakan soal nomor 2 yaitu soal TIMSS tentang aljabar yang sudah diterjemahkan kedalam bahasa Indonesia.

Pada tahap inkubasi siswa mampu memikirkan langkah-langkah pengerjaan dengan baik, meskipun ada yang terlupa berkaitan dengan penjumlahan dalam bentuk aljabar. Pada tahap iluminasi siswa ditanya tentang apa rencana untuk menyelesaikan soal nomor 2, kemudian siswa menyampaikan rencana penyelesaian masalah dengan menyamakan penyebutnya menjadi 8 , kemudian siswa ditanya bagaimana merubah pembilangnya, siswa menjawab penyebut yang baru dibagi dengan penyebut yang sebelumnya kemudian dikalikan dengan pembilangnya. Berikut merupakan hasil pekerjaan siswa mengerjakan soal nomor 2 .

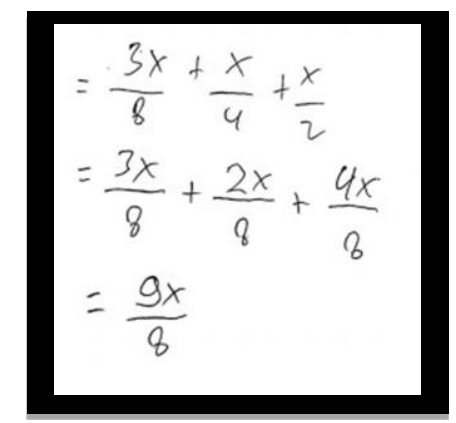

Gambar 4. Hasil pekerjaan siswa berkemampuan tinggi soal nomor 2 
Gambar 4 menunjukkan hasil pekerjaan siswa berkemampuan tinggi mengerjakan soal nomor 2 dengan sekali pengerjaan karena siswa sudah memahami maksud soal dan siswa masih mengingat bagaimana pengerjaan soal bentuk pecahan tersebut. Pada tahap verifikasi siswa ditanya apakah sudah yakin dengan jawabannya atau ada jawaban yang lain. Siswa menjawab yakin dengan pengerjaannya tanpa mengecek ulang jawabannya.

Pada soal nomor 3 siswa bergaya kognitif visualizer yang memiliki kemampuan matematika tinggi mampu menyelesaikan soal nomor 3 dengan benar.

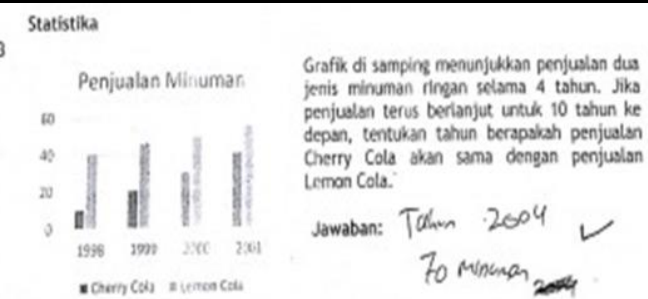

Grafix di samping menunjukkan penjualan dua jenis minuman rimgan selama 4 tahun. Jika penjuelan terus berlanjut untuk 10 tahun ke Cherry Cola akan sama dengan penjualan imon Cola.

Jawaban: Tahm 2004 v 70 Minuman

Gambar 5. Soal nomor 3 dan jawaban siswa berkemampuan tinggi

Gambar 5 merupakan soal nomor 3 yaitu soal TIMSS tentang statistika yang sudah diterjemahkan kedalam bahasa Indonesia.

Pada tahap persiapan siswa memahami maksud soal nomor 3, ditahap inkubasi siswa juga sudah memikirkan langkah pengerjaannya. Yang menarik pada tahap iluminasi siswa ditanya tentang apa rencana untuk menyelesaikan soal nomor 3. Siswa menentukan polanya terlebih dahulu, pola dari kenaikan penjualannya untuk masing-masing barang yang dijual. Setelah itu siswa menyampaikan setelah diketahui pola kenaikannya maka penjualan akan sama diangka 70. Siswa tidak menggambarkan kembali grafik dan menyelesaikan soal ini dengan membayangkan ditahun berapa penjualan akan sama. Hasil wawancara menunjukkan bahwa siswa yang berkampuan tinggi mampu menjawab soal nomor 3 hanya dengan membayangkan dan melihat dari pola kenaikan penjualannya yang naik 3 kali untuk mendapatkan penjualan yang sama, maka penjualan akan sama di 3 tahun setelahnya yaitu pada tahun 2004. Pada tahap verifikasi siswa ditanya apakah siswa yakin dengan jawabannya atau ada jawaban lain. Siswa tersebut menjawab yakin bahwa jawabannya benar.

\section{B. Subjek Berkemampuan Sedang}

Hasil penelitian pada subjek bergaya kognitif visualizer yang memiliki kemampuan matematika sedang yaitu pada soal nomor 1 subjek berhasil mengerjakan soal dengan baik. Pada tahap persiapan siswa sudah paham maksud dari soal.

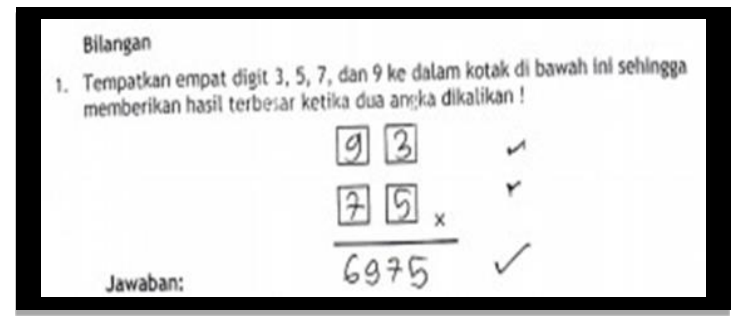

Gambar 6. Soal nomor 1 dan jawaban siswa berkemampuan sedang 
Gambar 6 merupakan soal nomor 1 yaitu soal TIMSS tentang bilangan yang sudah diterjemahkan kedalam bahasa Indonesia.

Pada tahap inkubasi siswa mampu memikirkan langkah pengerjaan dengan baik dan tidak memiliki masalah siswa sudah mengetahui apa yang dimaksud dari soal nomor 1. Pada tahap iluminasi siswa ditanya bagaimana rencana untuk menyelesaikan masalah soal nomor 1 , siswa menyampaikan bahwa siswa menyelesaikannya dengan cara trial and error atau coba-coba. Siswa melakukan uji coba mengalikan sampai 3 kali, setelah itu baru mendapatkan jawaban yang terbesar. Saat siswa ditanya mengapa memilih angka yang terbesar menjadi puluhan, siswa menjawab karena yang diminta hasil terbesar sehingga siswa memilih puluhan dari angka yang terbesar sehingga diketahui jawaban yang benar yaitu 6975.

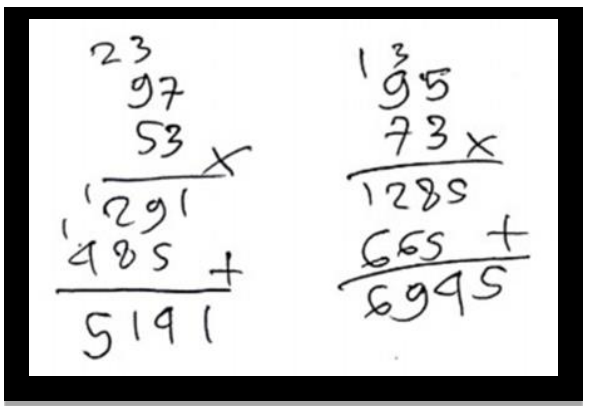

Gambar 7. Hasil pekerjaan siswa berkemampuan sedang soal nomor 1

Gambar 7 menunjukkan hasil pekerjaan siswa berkemampuan sedang mengerjakan soal nomor 1 . Siswa mengerjakan soal nomor 1 dengan trial and error sampai 3 kali, dan gambar diatas

Mosharafa: Jurnal Pendidikan Matematika

Volume 8, Nomor 1, Januari 2019

Copyright @ 2019 Mosharafa: Jurnal Pendidikan Matematika merupakan 2 kali percobaan yang salah dan jawaban yang benar dan paling besar siswa memilih angka 93 dan 73 maka didapatkan jawaban yang terbesar yaitu 6975. Pada tahap verifikasi siswa ditanya apakah yakin dengan jawabannya, siswa kemudian menjawab sangat yakin karena saya sudah mencobanya sebanyak 3 kali.

Pada soal nomor 2 siswa masih bingung untuk menyelesaikan soal aljabar dengan operasi bentuk pecahan, atau bisa dikatakan siswa yang berkemampuan sedang sering lupa akan konsep penjumlahan bentuk pecahan. Pada tahap persiapan siswa ditanya apa maksud dari soal nomor 2, siswa menjawab bahwa siswa masih bingung untuk memahami soal nomor 2. Berikut merupakan contoh soal dan jawaban siswa.

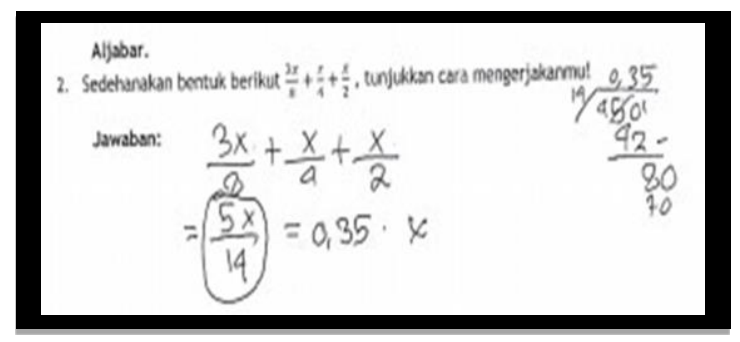

Gambar 8. Soal nomor 2 dan jawaban siswa berkemampuan sedang

Gambar 8 merupakan soal nomor 2 yaitu soal TIMSS tentang aljabar yang sudah diterjemahkan kedalam bahasa Indonesia. Pada tahap inkubasi siswa masih bingung memikirkan langkahlangkah penyelesaiannya hal ini terlihat saat wawancara. Pada tahap iluminasi siswa ditanya tentang rencana penyelesaiannya, kemudian siswa menyampaikan cara pengerjaan yang salah 
dimana siswa langsung menjumlahkan penyebut dan pembilangnya tanpa menyamakan penyebutnya terlebih dahulu. Pada tahap verifikasi siswa ditanya berkaitan dengan soal, terlihat siswa bingung namun setelah diingatkan berkaitan dengan syarat penjumlahan bentuk pecahan siswa berkemampuan sedang mampu mengerjakan soal ini.

Pada soal nomor 3 subjek bergaya kognitif visualizer yang berkemampuan matematika sedang, dapat menyelesaikan soal nomor 3 dengan benar, siswa yang berkemampuansedang ini masih dapat memahami maksud dari soal nomor 3 tentang statistika.

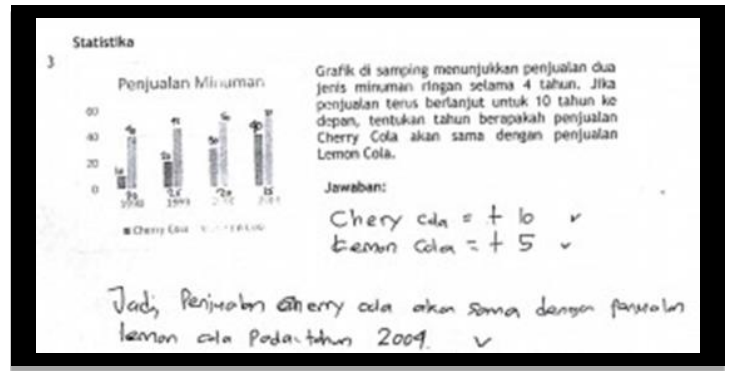

Gambar 9. Soal nomor 3 dan jawaban siswa berkemampuan sedang

Gambar 9 merupakan soal nomor 3 yaitu soal TIMSS tentang statistika yang sudah diterjemahkan ke dalam bahasa Indonesia.

Pada tahap persiapan siswa mampu memahami maksud dari soal nomor 3, pada tahap inkubasi siswa mampu memikirkan langkah-langkah yang akan dilakukan untuk menyelesaikan soal nomor 3. Menariknya pada tahap iluminasi siswa ditanya bagaimana rencana untuk menyelesaikan soal nomor 3. Siswa

menyampaikan pada saat wawancara yaitu: 1) melihat pola kenaikan penjualannya terlebih dahulu. Setelah itu siswa berkemampuan sedang ini melanjutkan menggambar grafiknya sampai diketahui penjualan yang sama sebanyak 70 di tahun 2004. Pada tahap verifikasi subjek ditanya apakah yakin dengan jawabannya, kemudian siswa menjawab yakin dengan jawaban yang telah didapatkannya. Diakhir wawancara siswa menyampaikan bahwa subjek ini lebih suka menyelesaikan masalah dengan cara yang sederhana tanpa menggunakan rumus yang rumit.

\section{Subjek Berkemampuan Rendah}

Hasil penelitian pada subjek bergaya kognitif visualizer yang memiliki kemampuan matematika rendah masih kesulitan memahami maksud soal yang berhubungan dengan suatu hal yang abstrak. Soal nomor 1, pada tahap persiapan siswa masih kebingungan memahami maksud dari soal. Namun setelah itu siswa memahami sendiri apa yang diminta dari soal nomor 1.

Pada tahap inkubasi subjek mampu untuk menentukan langkah-langkah untuk menyelesaikan soal nomor 1 . Tahap iluminasi siswa ditanya tentang bagaimana rencana untuk menyelesaikan soal nomor 1, siswa menyampaikan bahwa untuk menyelesaikan soal nomor 1 siswa menggunakan cara trial and error sampai 3 kali sampai ditemukan hasil yang terbesar. Berikut merupakan hasil pekerjaan siswa menyelesaikan soal nomor 1 . 


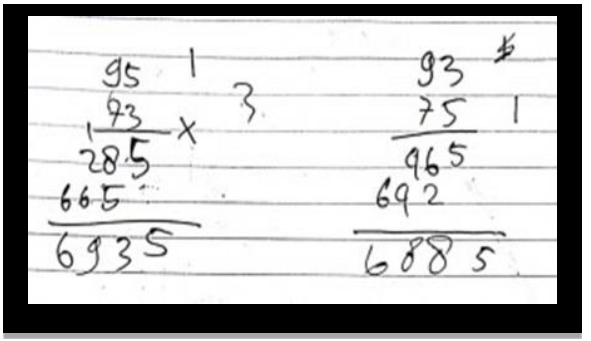

Gambar 10. Hasil pekerjaan siswa berkemampuan rendah soal nomor 1

Gambar 10 menunjukkan hasil pekerjaan siswa berkemampuan rendah mengerjakan soal nomor 1. Gambar diatas merupakan 2 kali percobaan siswa yang belum mendapatkan hasil terbesar. Berikut merupakan jawaban lainnya yang merupakan hasil terbesar.

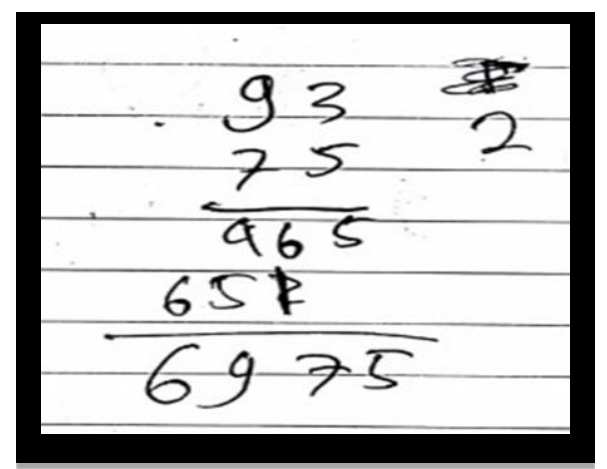

Gambar 11. Hasil pekerjaan siswa berkemampuan rendah soal nomor 1

Pada penyelesaian soal nomor 1 ini siswa bingung memahami maksud soal. Namun setelah membaca soal beberapa kali siswa dapat memahami soal nomor 1 , yang akhirnya dapat menemukan hasil yang terbesar setelah dipercobaan ketiga.

Pada pengerjaan soal nomor 2 pada tahap persiapan, siswa ditanya tentang maksud soal dan siswa kebingungan dengan soal nomor 2. Pada tahap inkubasi siswa tidak mengerti sama sekali langkah- langkah penyelesaian soal nomor 2. Pada tahap iluminasi siswa berkemampuan rendah tidak ada rencana penyelesaian soal nomor 2, dikarenakan siswa belum mampu memahami soal yang bersifat abstrak dan lupa akan cara penyelesaian penjumlahan pecahan bentuk aljabar.

Penyelesaian soal yang menarik pada siswa yang berkemampuan rendah adalah pada penyelesaian soal nomor 3. Siswa berkemampuan rendah bisa mengerjakan soal nomor 3 dengan baik dan benar. Pada tahap persiapan setelah siswa diberikan lembar soal diantara ketiga soal, soal yang pertama kali dikerjakan adalah soal nomor 3. Hal tersebut menunjukkan bahwa siswa langsung memahami maksud dari soal nomor 3 dengan baik. Berikut merupakan soal dan jawaban siswa menyelesaikan soal nomor 3 .

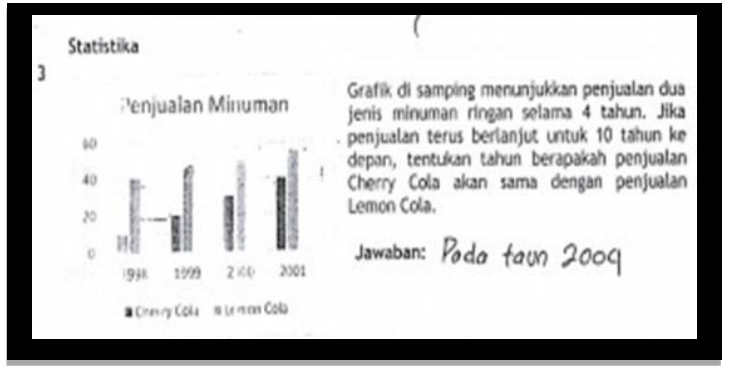

Gambar 12. Soal nomor 3 dan jawaban siswa berkemampuan rendah

Gambar 12 merupakan soal nomor 3 yaitu soal TIMSS tentang statistika yang sudah diterjemahkan ke dalam bahasa Indonesia. Pada tahap inkubasi siswa bisa menentukan langkah-langkah penyelesaian dengan baik. Pada tahap iluminasi siswa ditanya bagaimana rencana untuk menyelesaikan soal nomor 3. Pada 
saat wawancara siswa menyampaikan untuk menyelesaikan soal nomor 3 yaitu dengan menentukan pola penjualannya dan mengurutkannya. Berikut merupakan hasil pekerjaan siswa berkemampuan rendah menyelesaikan soal nomor 3 .

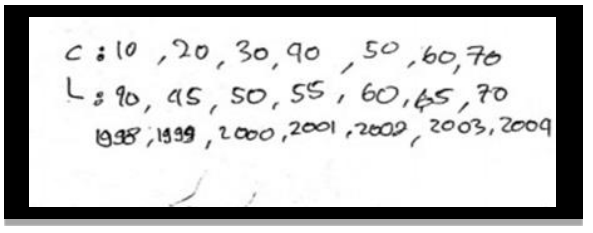

Gambar 13. Hasil pekerjaan siswa berkemampuan rendah soal nomor 3
Gambar 13 merupakan hasil penyelesaian soal nomor 3 yang dikerjakan oleh siswa berkemampuan rendah. Siswa menyelesaikan soal nomor 3 dengan cara melihat polanya dan mengurutkan berdasarkan penjualan dan tahunnya. Sehingga didapat hasil penjualan yang sama sebanyak 70 ditahun 2004. Pada tahap verifikasi siswa ditanya apakah yakin dengan jawabannya. Siswa menjawab yakin dengan jawabannya.

Tabel 1.

Kesimpulan akhir semua subjek bergaya kognitif visualizer

\begin{tabular}{lccc|}
\hline & Subjek Berkemampuan Tinggi & $\begin{array}{c}\text { Subjek Berkemampuan } \\
\text { Sedang }\end{array}$ & $\begin{array}{c}\text { Subjek Berkemampuan } \\
\text { Rendah }\end{array}$ \\
\hline Tahap Persiapan & Baik & Baik & Cukup \\
\hline Tahap Inkubasi & Baik & Cukup & Cukup \\
\hline Tahap Iluminasi & Baik & Cukup & Kurang \\
\hline Tahap Verifikasi & Cukup & Cukup & Kurang \\
\hline
\end{tabular}

\section{Temuan Penelitian}

Berdasarkan hasil tes, wawancara, dan hasil pengamatan terhadap subjek, temuan dari penelitian ini adalah sebagai berikut:

1. Subjek bergaya kognitif visualizer dengan kemampuan matematika yang tinggi, mampu melakukan langkah proses berpikir dengan baik, walaupun ada sedikit nama konsep yang terlupa. Siswa mampu berpikir dan mencurahkan ide-ide yang baik untuk menyelesaikan soal. Subjek berkemampuan tinggi terbukti lebih baik dalam menyelesaikan permasalahan TIMSS non geometri meskipun siswa ini bergaya kognitif visualizer.

2. Subjek dengan kemampuan matematika sedang sudah cukup baik dalam memahami soal. Terbukti siswa masih lemah dalam memahami soal yang abstrak seperti salah memahami soal nomor 2 yang berupa penjumlahan aljabar dalam bentuk pecahan. Hal ini menunjukkan bahwa siswa bergaya kognitif visualizer untuk siswa yang berkemampuan matematika sedang masih lemah untuk soal yang tidak melibatkan gambar ataupun grafik.

3. Subjek bergaya kognitif visualizer dengan kemampuan matematika yang 
rendah bingung memahami soal memahami soal, siswa juga tidak bisa TIMSS non geometri. Dari hasil menyampaikan pendapatnya dengan pekerjaan siswa terbukti hanya mampu memahami satu soal yaitu soal nomor 3 yang berupa statistika yang masih ada grafiknya.

\section{Penutup}

Temuan penelitian "Proses Berpikir Siswa Bergaya Kognitif Visualizer Dalam Menyelesaikan Masalah TIMSS Non Geometri" telah menjawab rumusan masalah yang disusun peneliti tentang bagaimana proses berpikir siswa bergaya kognitif visualizer dalam menyelesaikan masalah TIMSS non geometri, setiap subjek proses berpikirnya berbeda-beda. Dipilihnya soal TIMSS non geometri dimaksudkan untuk mengetahui bagaimana proses berpikirnya siswa yang bergaya kognitif visualizer dalam menyelesaikan soal TIMSS non geometri. Siswa yang berkemampuan tinggi secara keseluruhan sudah paham dengan 3 soal TIMSS, meskipun soal yang diberikan termasuk soal yang non geometri yang tidak terdapat gambar sama sekali. Siswa yang bergaya kognitif visualizer dengan kemampuan matematika sedang dalam memahami soal secara keseluruhan sudah cukup baik, dari 3 soal yang berhasil dikerjakan dengan benar hanya 2 soal. Siswa yang berkemampuan sedang belum mampu memahami soal yang bersifat abstrak seperti aljabar yaitu soal nomor 2 . Siswa yang bergaya kognitif visualizer dengan kamampuan matematika rendah secara keseluruhan masih lemah dalam bahasa sendiri. Diantara 3 soal yang dijawab benar hanya 2 soal namun yang paling dipahami dari ketiga soal adalah soal nomor 3 karena masih terdapat grafik yang membantunya untuk memahami maksud soal. Untuk penelitian lanjut yang sejenis disarankan peneliti menggunakan soal TIMSS yang lain atau digunakan mata pelajaran lain untuk mengetahui proses berpikir siswa.

\section{UCAPAN TERIMA KASIH}

Ucapan terima kasih ini penulis tujukan Kepada STKIP Al Hikmah Surabaya yang telah memberikan kesempatan kepada penulis untuk melakukan penelitian kualitatif.

\section{Daftar PUstaka}

Agasi, G.R., \& Rudhito, M. A. (2014). Kemampuan siswa kelas VIII dalam menyelesaikan soal-soal TIMSS tipe penalaran.

Hermawan, T. (2003). TIMSS dan Implikasinya Terhadap Pendidikan Mate- matika di Indonesia. Mimbar Pendidikan, (2), 12-18.

Hegarty, M., \& Kozhevnikov, M. (1999).Types of visual-spatial representations and mathematical problem solving. Journal of educational psychology, 91(4), 684.

Nadhifah, G \& Afriansyah, E. A. (2017). Peningkatan Kemampuan Pemecahan Masalah Matematis Siswa dengan Menerapkan Model Pembelajaran Problem Based Learning dan Inquiry. Mosharafa: Jurnal Pendidikan 
Matematika, 5(1), 33-44.

Febriani, S. \& Ratu, N. (2018). Profil proses berpikir kreatif matematis siswa dalam pemecahan masalah openended berdasarkan teori Wallas. Mosharafa: Jurnal Pendidikan Matematika, 7(1), 39-50.

Sari, E. M. J. (2016). Profil berpikir kritis siswa SMP dalam menyelesaikan masalah geometri ditinjau dari gaya kognitif visualizer dan verbalizer. MATHEdunesa, 2(5), 39-47.

Sholihah, S. \& Afriansyah, E. A. (2017). Analisis Kesulitan Siswa dalam Proses Pemecahan Masalah Geometri Berdasarkan Tahapan Berpikir Van Hiele. Mosharafa: Jurnal Pendidikan Matematika, 6(2), 287-298.

Soedjadi, R. (2000). Kiat Pendidikan Matematika Di Indonesia. Konstatasi Keadaan Masa Kini Menuju Harapan Masa Depan. Jakarta: Direktorat Jenderal Pendidikan Tinggi, Departemen Pendidikan Nasional.

Sugiyono, P. Dr. 2010. Metode Penelitian Kuantitatif, Kualitatif, dan R\&D. Bandung: CV Alfabeta.

Susan, H. dan Collinson, G. (2005). Achieving Evidence- Based Practice: A Handbook for Practitioners. Second Edition. Elsevier

Uno, H. B. (2006). Orientasi baru dalam psikologi pembelajaran. Jakarta: Bumi Aksara.

Winarso, W., \& Dewi, W. Y. (2017). Berpikir kritis siswa ditinjau dari gaya kognitif visualizer dan verbalizer dalam menyelesaikan masalah geometri. Beta Jurnal Tadris Matematika, 10(2), 117-133.

\section{Riwayat Hidup PENULIS}

\section{Rohman Galih Tri Mulyo, S.Pd.}

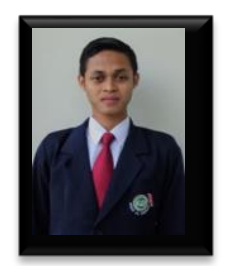

Lahir di Kabupaten Nganjuk, Jawa Timur 9 Januari 1998. S1 Pendidikan Matematika STKIP Al Hikmah Surabaya. Juara 2 desain aplikasi komputer Al Qur'an dalam ajang MTQMR V Jawa Timur di Universitas Negeri Jember tahun 2018. Pemakalah di seminar Nasional Pendidikan Matematika Universitas PGRI Adi Buana Surabaya 2018.

Anisa Fatwa Sari, S.Pd., M.Sc.

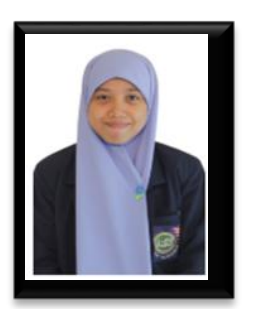

Lahir di Kabupaten Mojokerto Jawa Timur 25September 1987, dosen Pendidikan Matematika di STKIP Al Hikmah, S1 Pendidikan Matematika Universitas Negeri Surabaya lulus tahun 2010. S2 Pendidikan Matematika Universitas Negeri Surabaya lulus tahun 2012.

\section{Azhar Syarifuddin, S.Pd., M.Si.}

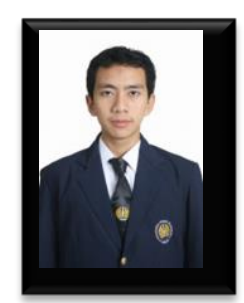

\begin{tabular}{llr} 
Lahir di & \multicolumn{2}{r}{ Kabupaten } \\
Lamongan Jawa & Timur & 12 \\
Maret & 1991, dosen \\
Pendidikan & Matematika di \\
STKIP Al Hikmah, S1 & Hatematika \\
Pendidikan & Matera \\
Universitas & Negeri Surabaya
\end{tabular} lulus tahun 2013. S2 Matematika Institut Teknologi Bandung lulus tahun 2016. Publikasi terbaik dengan judul "Construction of Cyclic Codes Over Ternary Field From Periodic Sequences" di Southeast Asian Bulletin of Mathematic (2018) 42:773-780. 